\title{
\#ForgiveUsForWeHaveSinned: Conceptual integration theory and political Internet humour
}

\author{
Nihada Delibegović Džanić \\ University of Tuzla, Bosnia and Herzegovina \\ nihada.delibegovic@untz.ba
}

\section{Sanja Berberović}

University of Tuzla, Bosnia and Herzegovina

sanja.berberovic@untz.ba

\begin{abstract}
The aim of the paper is to uncover the extent to which different forms of political Internet humour can criticise current political affairs in a developing democracy such as Bosnia and Herzegovina. Specifically, applying a cognitive linguistic theory of meaning construction, namely conceptual integration theory, the paper analyses the construction of meaning of humorous Internet forms, such as memes, demotivational posters, hashtag posts, and memetic photographs, representing innovative ways of providing political commentaries on current political affairs. The meaning of political humour is constructed in conceptual blending as a basic cognitive mechanism. As it is claimed (Coulson \& Pascual 2006, Coulson \& Oakley 2006, Coulson 2006, Oakley \& Coulson 2008) that blending can be used as a rhetorical tool influencing the audience to change the reality and even act upon it, the analysis of the construction of meaning of political humour as products of conceptual integration can reveal hidden ideologies in political discourse.
\end{abstract}

Keywords: conceptual integration theory, political Internet humour, political discourse, public discourse, rhetorical goals.

\section{Introduction}

Political humour ridicules politicians and their political parties, social institutions, political systems, ideas and situations of everyday life. It can be claimed that political humour has been around as long as politics itself, although it has had many different forms throughout history. While the main aim of political humour is to entertain, a far more important aim of political humour is to criticise political actors and political systems and challenge their views by poking fun at the absurdities of politics. In societies in which freedom of speech is limited, political 
humour has an even more important role, that is, political humour can have a subversive power, uncovering hidden ideas and viewpoints and promoting forbidden political opinions.

As the essence of democracy lies in the possibility to express different views freely, challenge widely held beliefs publicly and criticise those in power, it is a common practise in the contemporary democratic societies to use humour to express opposing political views. In highly developed democracies, the criticism of democratic processes through humour in public discourse, ranging from jokes and political cartoons to late-night comedy shows, has proven to be very powerful. Such power lies in engaging an apathetic public in democratic processes, as well as revealing hidden ideologies. All of these different forms of criticism provide an insight into how democratic societies and individuals think and behave politically. Considering that Bosnia and Herzegovina, almost two decades after the war, is still struggling to embrace the basic principles of democracy, it is not surprising that such practises in the public sphere in Bosnia and Herzegovina have been scarce or even non-existent. It is only recently that new forms of criticism have been gradually emerging on social media and the Internet as forms of expressing opposition to incompetent and arrogant politicians.

The aim of the paper is to uncover the extent to which different forms of political Internet humour can criticise current political affairs in a developing democracy such as Bosnia and Herzegovina. Specifically, applying a cognitive linguistic theory of meaning construction, namely Fauconnier and Turner's conceptual integration theory, the paper analyses the construction of meaning of humorous Internet forms, such as memes, demotivational posters, hashtag posts, and memetic photographs, representing innovative ways of providing political commentaries on current political affairs. It also discusses how political humour, as a product of conceptual integration, contributes to highlighting certain aspects of reality thus achieving rhetorical goals.

The paper is organised as follows: in part two of the paper we provide an overview of conceptual integration theory. Part three discusses the role of conceptual integration in the creation of humorous meaning, as well as its understanding. Applying conceptual integration theory, part four presents the analysis of the examples of political Internet humour on the topic of the socio-economic situation in Bosnia and Herzegovina. Part five discusses the creation of humour and its appreciation in light of conceptual integration theory. Finally, the paper presents general conclusions drawn from the analysis.

\section{Conceptual integration theory}

The origins of conceptual integration theory, or blending theory, can be traced back to 1993, when Fauconnier and Turner introduced this theory. The basic ideas behind conceptual integration theory have since been elaborated in the works of Fauconnier \& Turner (2006 [1998], 2000, 2002), Turner \& Fauconnier (1995, 1999, 2003), Turner (2007), Coulson \& Oakley (2000), Grady et al. (1999). Conceptual blending is a basic cognitive operation, "highly creative but crucial to even the simplest kinds of thought" (Fauconnier \& Turner 2002: 18).

Fauconnier \& Turner built conceptual integration theory on the foundations of Fauconnier's (1985) mental space theory. Fauconnier (2007: 351) defines mental spaces as "very partial assemblies constructed as we think and talk for purposes of local understanding and action". Fauconnier (2007: 351) adds that frames and cognitive models structure mental spaces, which are connected by mappings and are modified throughout the discourse. Based on mental space theory, conceptual integration theory has emerged as a theory that can be applied to a wide variety of linguistic phenomena, from meaning construction to grammatical patterns. Furthermore, the theory has found its application in explaining the construction of meaning in non-linguistic blends, as well. "Blending can be detected in everyday language, 
idioms, creative thought in mathematics, evolution of socio-cultural models, jokes, advertising, and other aspects of linguistic and non-linguistic behavior" (Turner \& Fauconnier 1995: 186). Therefore, conceptual integration theory has become a theory that can explain the complexities of human mind.

The central idea behind blending as a basic cognitive operation is that it operates over a conceptual integration network, which comprises mental spaces and relations holding between them. "Building an integration network involves setting up mental spaces, matching across spaces, projecting selectively to a blend, locating shared structures, projecting backward to inputs, recruiting new structure to the inputs or the blend, and running various operations in the blend itself" (Fauconnier \& Turner 2002: 44). All of these processes represent the constitutive principles on which the conceptual integration rests. As blending is an online, dynamic process, these operations can occur at any time, as well as simultaneously. Therefore, the diagrams representing conceptual integration networks are simply one-shot previews of one of the stages of this complex mental operation, which should not be thought of as a static operation. The diagram below presents the basic conceptual integration network.

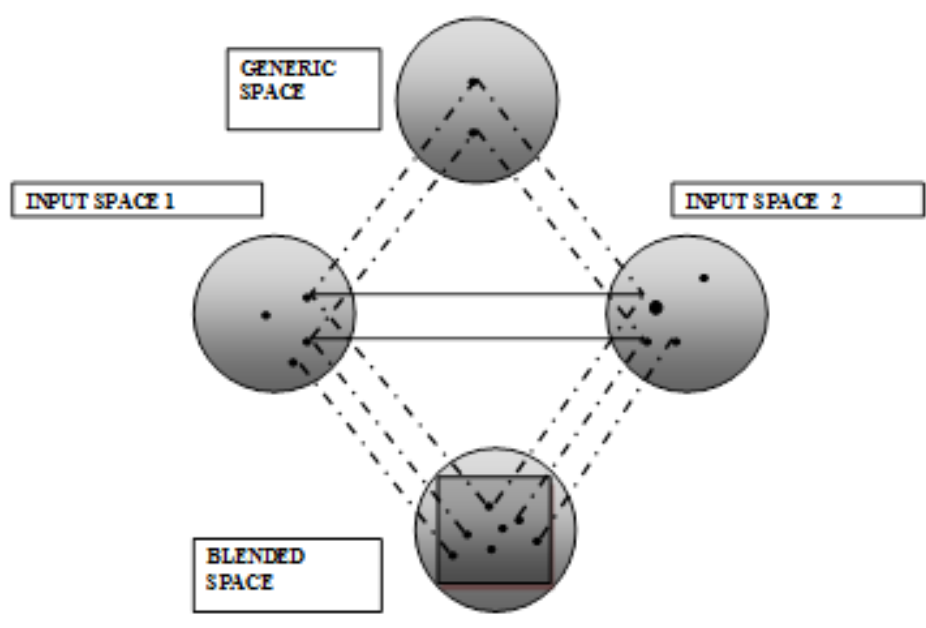

Figure 1. The basic diagram presenting the conceptual integration network (Fauconnier \&

Turner 2002: 46)

As the diagram shows, the conceptual integration network is composed of two input spaces, a generic space, and a blended space, although a single network can be composed of several input as well as blended spaces. Mental spaces contain elements and relations that have their internal organisation. The solid lines between input spaces are counterpart connections established in the process of partial matching. "Such counterpart connections are of many kinds: connections between frames and roles in frames, connections of identity or transformation or representation, analogical connections, metaphoric connections, and, more generally, 'vital relations' mappings" (Fauconnier \& Turner 2002: 47). The dotted lines between the generic space and the input spaces represent the connection of the elements that seem to be shared by the inputs. The generic space captures the shared elements of both inputs and these elements from the generic space are in turn mapped onto the counterpart elements in the input spaces. The dotted lines between the inputs and the blend represent the structure from the inputs being projected to the blend, a new mental space. "Blends contain generic structure captured in the generic space but also contain more specific structure, and they can contain structure that is impossible 
for the inputs, [...]" (Fauconnier \& Turner 2002: 47). However, not all elements from the inputs get projected to the blend, which means that projections from the input spaces to the blend are partial.

The emergent structure, represented in the diagram by the solid square in the blended space, is not copied from either input. Rather, the new structure in the blend is generated in three ways, namely through the processes of composition, completion, and elaboration, which operate unconsciously. "Composition, completion, and elaboration all recruit selectively from our most favored patterns of knowing and thinking" (Fauconnier \& Turner 2006 [1998]: 339). Composition refers to the projection of elements from the input spaces into the blended spaces and the creation of relations that do not exist in the inputs. "Completion is the filling out of a pattern in the blend, evoked when structure projected from the input spaces matches information in long-term memory" (Grady et al. 1999: 107). This means that, in the completion process, the background knowledge and structure are brought into the blend unconsciously. Elaboration is mental simulation of the event in the blend, which can be performed indefinitely. Elaboration enables the blend to run in many different directions.

Mental spaces in an integration network can be modified at any point of the construction of the network. In addition, input spaces can be modified by backward projections from the blended space. Therefore, the construction of the integration network is a dynamic process, allowing modifications at any stage of the process of construction.

\section{Conceptual integration theory in humour}

As Fauconnier \& Turner (2002: 18) put it, "blending is an invisible, unconscious activity involved in every aspect of human life". Therefore, it is not surprising that conceptual integration theory has found its application in the study of different types of humour in a number of papers in recent years (Bergen 2004; Berberović \& Delibegović Džanić 2009, 2015; Coulson 2002, 2005; Delibegović Džanić 2013; Delibegović Džanić \& Berberović 2010, 2014; Delibegović Džanić \& Omazić 2011; Kyratzis 2003; Lundmark 2003; Marín-Arrese 2003). Coulson (2002) claims that "[ $\mathrm{t}]$ hough not all blends are humorous, blending does seem to be an inherent feature of humour".

The view that humour is generated through the combination of different frames or input spaces can be traced back to Koestler's quotation presented below.

The sudden bisociation of an idea or event with two habitually incompatible matrices will produce a comic effect, provided that the narrative, the semantic pipeline, carries the right kind of emotional tension. When the pipe is punctured, and our expectations are fooled, the now redundant tension gushes out in laughter, or is spilled in the gentler form of the sou-rire.

(1964: 51, quoted in Coulson 2002)

Commenting on this hypothesis, Coulson (2002) emphasises that, in Koestler's view, humour includes "the unlikely combination of related structures".

In order to illustrate how conceptual integration theory explains the creation of humour, Coulson analyses the following joke.

(1) Why did the chicken cross the road? To get to the other side.

The conceptual integration network consists of two input spaces, one generic and one blended space. 


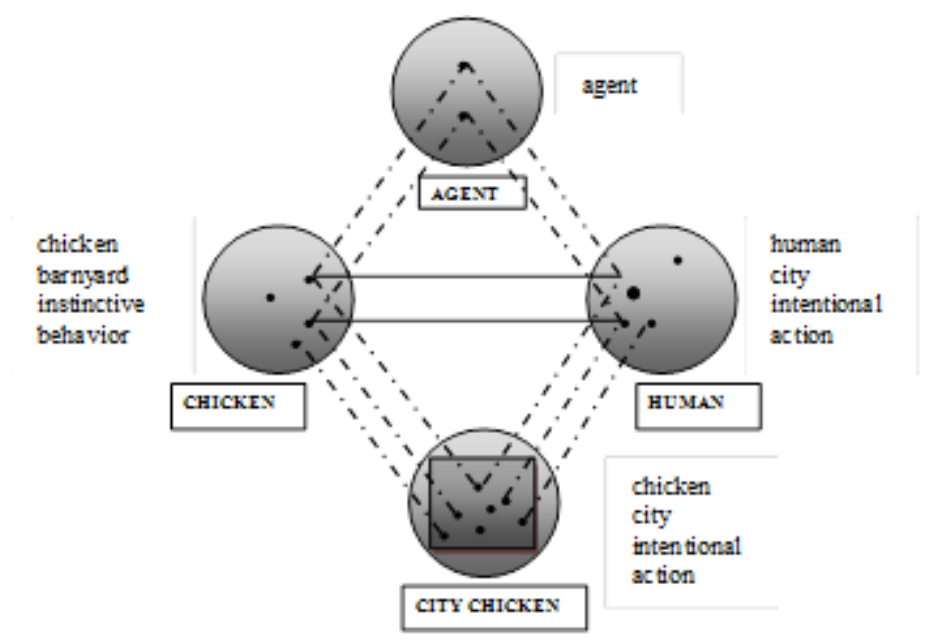

Figure 2. The conceptual integration network for the chicken joke (adapted from Coulson

2002)

Input space one contains chickens, which usually live in barnyards and behave instinctively. Input space two includes humans, who usually live in cities and act intentionally. Projections from input spaces to the blend result in the creation of a chicken that lives in the city and makes intentional decisions, behaving as a human being who intentionally crosses the road. The humour is created in the blended space, as the combination of a human being and chicken results in incongruity. The fact that chickens do not freely wander the streets and do not intentionally cross roads yields the incongruity in this joke and produces a humorous effect. It is important to point out that the emergent structure within the blend does not involve the creation of a creature that is a cross between a human and a chicken, but it actually contains a chicken with human-like intentions that lives in the world created in the joke. Cognitive linguists (Coulson 2002; Marín-Arrese 2003) claim that incongruity created in the blended space is the key element in the creation and appreciation of humour. In humorous blends, a new structure created in the blended space represents unusual combination of structures and produces "unexpected inferential and emotional effects which contribute to the humour appreciation" (Marín-Arrese 2003).

In addition, it can also be claimed that the incongruity is a main characteristic of humorous blends. However, what all blends have in common are backward projections from the blend into input spaces (Fauconnier \& Turner 2002). It is believed that this cognitive operation is a decisive element in the resolution of incongruity. In that sense, Marín-Arrese (2003) claims that " $[\mathrm{t}] \mathrm{he}$ problem solving or resolution of the incongruity is realised by projecting backward to these input spaces ...". Therefore, to resolve the incongruity, the reader has to unpack the blend, that is, to reconstruct the whole integration network. As Fauconnier \& Turner (2002: 333) claim, the reader first recognises the incongruity that then prompts him to reconstruct the input spaces. Furthermore, the humorous effect is produced in this process, that is, in the stages of the resolution of humour, when the reader recognises the incongruity and reinterprets the joke in accordance with the new meaning arising in the blend.

Furthermore, Coulson (2002) finds that the emergent structure in the blend can emphasise certain construals in the input spaces by projecting from the blended space to input spaces. In a series of papers, Coulson $(1996,2002,2005,2006)$ discusses jokes and political cartoons providing evidence that humorous blends, with bizarre concepts arising in the blended space, can promote certain aspects of reality. "Political cartoons and rhetorically motivated discourse prompt us to construct blended cognitive models and, in effective cases of rhetoric, desired inferences are analogically projected from blatantly unrealistic blended cognitive models to the 
real-world target domain" (Coulson 2006: 197-198). Therefore, backward projections from the blended space to input spaces reinforce construals in input spaces in accordance with the new structure created in the blend.

In that sense, it can be claimed that unrealistic scenarios arising in the blended space often have argumentative potential. In a series of papers Coulson and associates (Coulson 2006; Coulson \& Oakley 2006; Coulson \& Pascual 2006; Oakley \& Coulson 2008) discuss blending and its rhetorical potential. These papers find that conceptual integration as a basic cognitive mechanism can be used as a rhetorical tool influencing the audience to change the reality and even act upon it. Furthermore, analysing blending in persuasive discourse, Coulson \& Pascual (2006) find that conceptual integration of two scenarios in a single absurd scenario in the blended space presents an effective argumentative tactic. Although such blends are not constructed in order to be entertaining, creative, and humorous but in order to convince the addressee to change the current state of affairs or to persuade the addressee to change his or her convictions, what these blends and humorous blends have in common are unrealistic scenarios created in the blended space. As Coulson \& Pascual (2006: 156) claim, "the impossible images inherent in these blends are rhetorically effective because they present the speakers' argument in an economic and convincing/straightforward manner". Therefore, it can be argued that unrealistic blends have rhetorical power and can help the reader gain a new perspective on reality and possibly make him act to change the reality.

\section{Forgive us Fadil for we have sinned}

Ridiculing politicians, their statements and ideas using different forms of humour, from jokes and political cartoons to late-night comedy shows, in public discourse is a common practise in highly developed democracies. As a developing democracy, Bosnia and Herzegovina has still not opened up a space for criticism of democratic processes through humour in public discourse. This is especially evident in the lack of tradition of criticism of political reality as in comedy shows focusing on politics. Broadcasting and publishing political humour is still almost non-existent in Bosnia and Herzegovina. However, the emergence of the new media on the Internet has opened up a new space for political humour and somewhat blurred the boundaries between private and public political sphere. Therefore, a trend that has appeared recently to use new media, such as social networks and the Internet, shows an exercise of the freedom of expression on the part of individuals. The purpose of these new trends is to criticise current political affairs and the state of the society in general, mostly using humour. These humorous Internet forms include creative and humorous static images combining verbal and visual components that are spread via social networks or the use of audiovisual forms as a means of artistic presentation of viewpoints. These new forms of expression, which are transferred quickly via the Internet from user to user, provide an opportunity for all interested in politics to become active participants in public discourse. Although such forms of expression may represent mundane practises, considering their accessibility and ease of use, they have become a new arena for political discourse in which citizens can express their dissatisfaction with those in power.

The use of new forms of humorous expression to criticise political reality can be exemplified with the Forgive me Fadil campaign trending on social networks at the beginning of 2016. Namely, in January 2016, Fadil Novalić, prime minister of the Federation of Bosnia and Hezegovina ${ }^{2}$ stated that Bosnians were wastefully spending money on luxuries. Novalić, taking into consideration a list of ten best-selling items in two supermarket chains, concluded that Bosnians were living good lives and even had money to waste on luxuries such as coffee, wine, and cigarettes. Considering the fact that Bosnia and Herzegovina is the poorest country 
in the region with an alarmingly high unemployment rate $^{3}$, Novalić's claims provoked the anger of citizens who were shocked by his ignorance of the socio-economic situation in the country. These statements were also a topic of humorous comments on the Internet, for example Bosnian citizens responded to Novalić's claims in the cyber space using different humorous forms, from Internet memes to hashtag posts on various social media. Nevertheless, although different forms of humorous comments about Novalić's statement flooded social media, he claimed that he had simply told the truth and that people were reluctant to accept it.

The examples discussed below illustrate different forms of political Internet humour which appeared as the criticism of Novalić's ignorance. The examples, including memes, demotivational posters, hashtag posts and memetic photographs, have been taken from a Facebook group with around ten thousand members devoted to ridiculing Novalić's statements, as well as Twitter hashtag posts under \#fadileoprosti. As a reaction to Novalić's statements, the users of these social networks posted different humorous forms asking Fadil Novalic for forgiveness for various, often trivial and ordinary things and actions. Subsequently, the most popular ones were further shared and modified by the social media users. The examples analysed represent just a small sample of the most popular posts among users of the abovementioned social media.

Among various humorous forms used to comment on Fadil Novalić's statements there was a significant number of political Internet memes that were shared among social media users. ${ }^{4}$ By providing simple and often humorous commentary on current political topics, political Internet memes have rhetorical and argumentative potential.

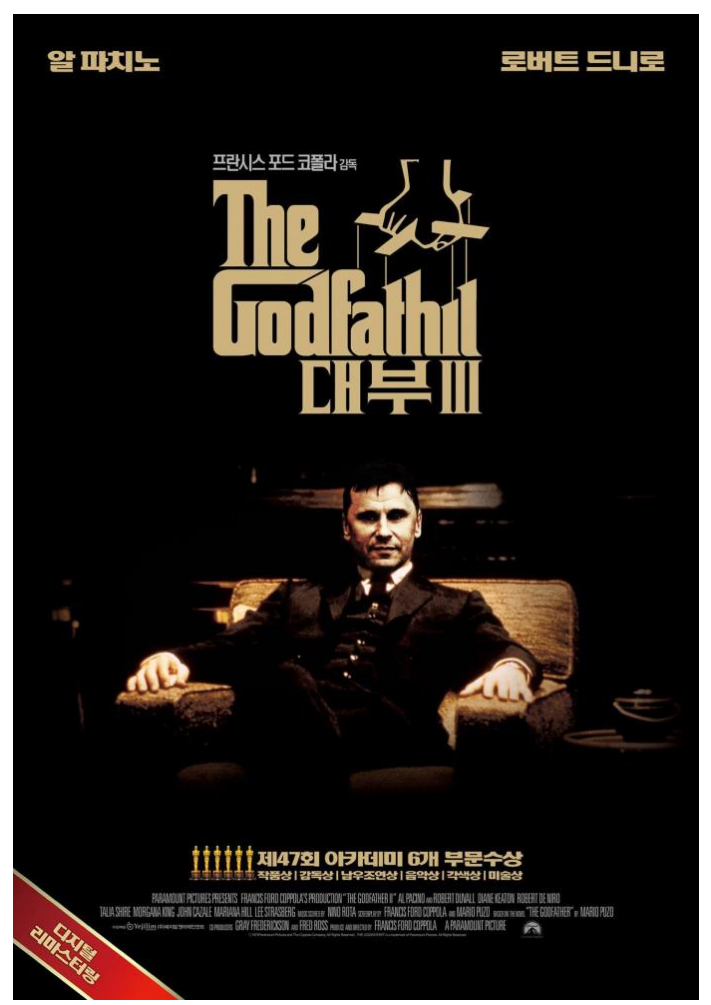

Figure 3. Fadil Novalić as the Godfathil. Source: Facebook

The humorous meaning of this meme is created in a four-space conceptual integration network composed of a generic space, two input spaces and a blended space. Input space one contains Fadil Novalić, prime minister of the Federation of Bosnia and Herzegovina, and his statement that people of Bosnia and Herzegovina were extravagant and recklessly wasteful because they 
spent money on mobile phones and other luxuries and not only essential products such as flour, oil and milk. Input space two contains the Godfather movie trilogy in which Vito Corleone, the Godfather, is the head of the Corleone mafia family, which is the most powerful mafia family in New York City. Vito controls a business founded on union corruption, gambling and bootlegging. The patriarch of the mafia family has to be asked for a permission for everything.

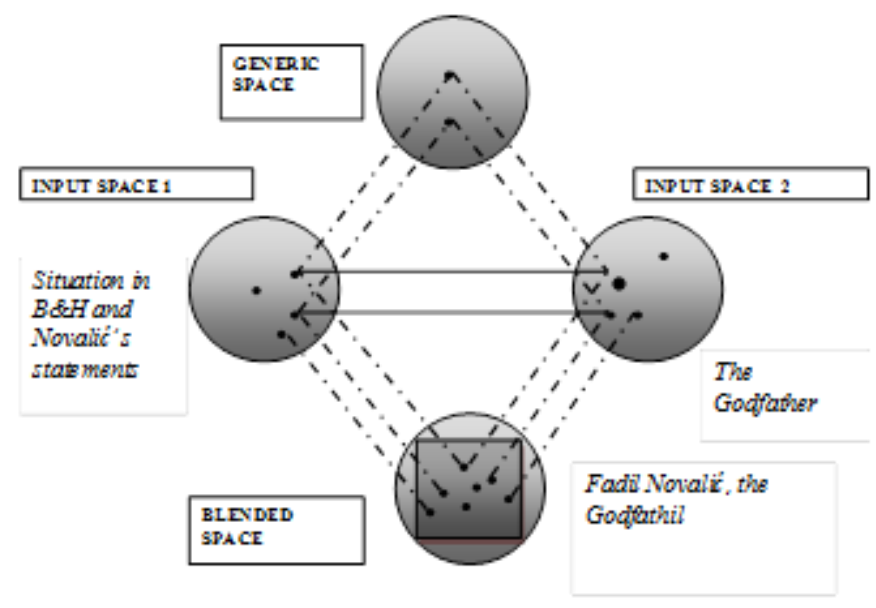

Figure 4. The conceptual integration network for the meme Fadil Novalić, the Godfathil

The inputs are connected by cross-space mappings linking Fadil Novalić from input space one with Vito Corleone, the head of the mafia family from input space two. Furthermore, the name of the Prime Minister, Fadil, from input space one and the word father from the title of the movie Godfather from input space two are connected by cross-space mappings as they are phonetically similar. The blend inherits the organising frame from input space two. Projected to the blend from input space one is Fadil Novalić and his statements. Projected to the blend from input space two is the Godfather and his role and duties as the patriarch of the mafia family. An absurd scenario that arises in the blend contains unusual combination of structures, that is, the incongruity, which produces humorous effects. In the emergent structure created in the blend Fadil Novalic is the Godfathil and he controls the spending of the citizens of the Federation of Bosnia and Herzegovina. Luxuries such as wine, cigarettes and coffee are certainly not approved by the Godfathil.

Apart from this and other similar memes, the social network Twitter was flooded with posts under the hashtag \#FadileOprosti (Forgive me Fadil). The hashtag text called out for the intervention of the Internet users through creative and humorous responses. These tweets poke fun at Novalić's statements on easy life in Bosnia and Herzegovina.

(2) Sve se nema, a tv u dnevnoj \#FadileOprosti

[You keep complaining, yet you have a TV in the living room. \#ForgivemeFadil]

(3) Sve se nema, mlakom vodom se suđe pere. \#FadileOprosti

[You keep complaining, yet you wash the dishes with lukewarm water. \#ForgivemeFadil]

(4) Jutros sam kaladontom oprao zube iako sam to i sinoć uradio prije spavanja \#FadileOprosti [I brushed my teeth with toothpaste this morning although I also did that last night before going to bed. \#ForgivemeFadil]

(5) Sve se nema, a vodokotlić se povlači. \#FadileOprosti

[You keep complaining, yet you flush the toilet. \#ForgivemeFadil] 
The humorous meaning of these tweets is created in a four-space conceptual integration network composed of two inputs, a generic space and a blended space. As in the previous example, input space one contains Novalić's claims about wasteful spending, as well as the difficult socio-economic situation in Bosnia and Herzegovina. Input space two contains a luxurious lifestyle which can be afforded only by the well-off people. Cross-space mappings connect the wasteful spending mentioned in Novalić's claims from input space one to the luxurious lifestyle from input space two.

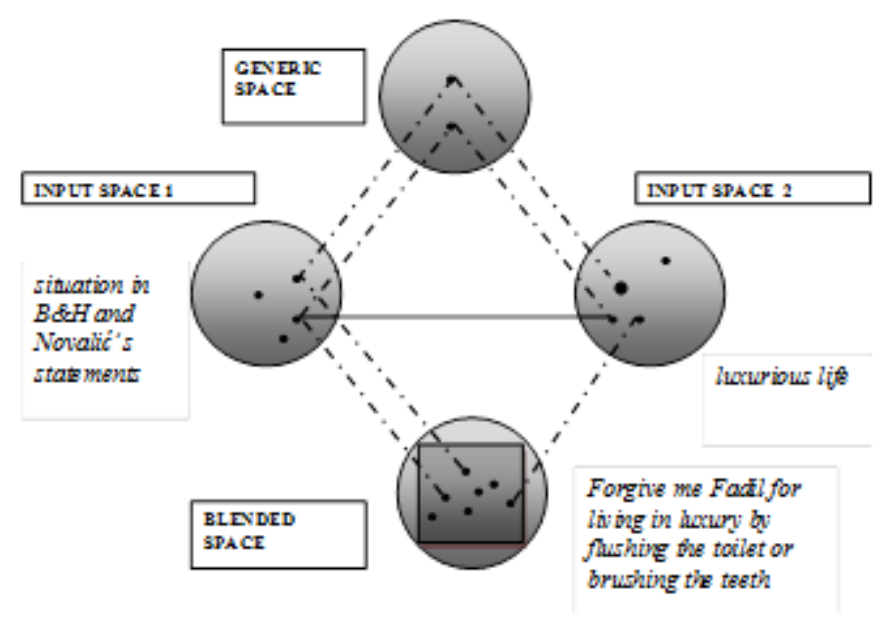

Figure 5. The conceptual integration network for the Forgive me Fadil hashtags

Projected to the blend are Fadil Novalic and the people of Bosnia and Herzegovina using ordinary products such as toothpaste and lukewarm water, and doing ordinary things such as flushing the toilet and owning a television set. Projected to the blend from input space two is the concept of life in luxury. The incongruity created in the blend produces humorous effects. In the absurd scenario created in the blend, Bosnians using products such as toothpaste, having a TV in the living room, washing the dishes with lukewarm water or flushing the toilet are asking for Fadil's forgiveness for living in luxury.

As these examples show, examples of living in luxury under the hashtag Forgive me Fadil flooded social networks. Successful humorous forms appearing on the Internet are often referred to, and even modified and repackaged into new creative forms, thus creating intertextual relations among humorous forms referring to the same issue. In that sense, the tweet below is a modified version of the previous examples and is part of the Forgive me Fadil Internet campaign.

(6) Sve se nema, a dva bubrega se nose. \#FadileOprosti

['You keep complaining, yet you have two kidneys. \#ForgivemeFadil']

The humorous meaning of this tweet arises in a five-space conceptual integration network composed of a generic space, three input spaces and a blended space. As in the previous example, input space one contains Fadil Novalić and his statement about luxurious life in Bosnia and Herzegovina. It also contains the socio-economic situation in Bosnia and Herzegovina, which is the poorest country in the region. Input space two contains a lifestyle characteristic of rich people, who can afford to spend money on luxuries without thinking. Input space three contains the knowledge about illegal organ trade. People living in poverty are often taken advantage of in illegal organ trade. The poor often sell their kidneys on the black 
market. As living a normal life without one kidney is possible, the underprivileged in many third world countries opt for selling this organ in order to improve their financial situation.

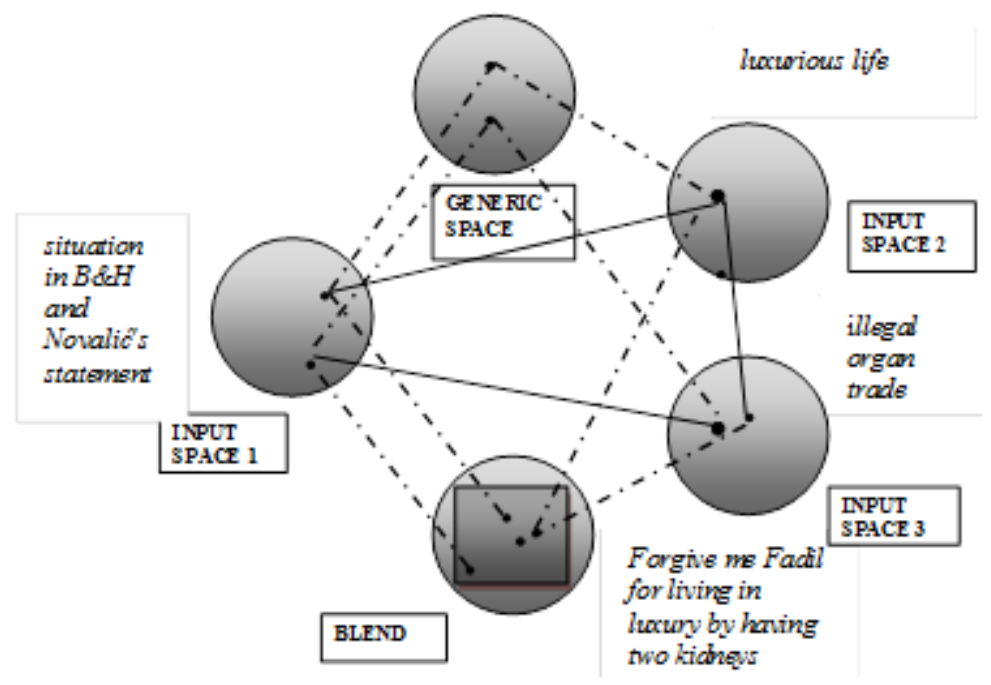

Figure 6. The conceptual integration network for the Forgive me Fadil for having two

kidneys joke

The inputs are connected by cross-space mappings linking the socio-economic situation in Bosnia from input space one to the socio-economic situation of people who sell their organs on the black market from input space three. In addition, cross-space mappings connect wasteful spending mentioned in Novalić's claims from input space one to the luxurious lifestyle from input space two. The blend inherits the organising frame from input space one. Projected to the blend from input space one is Fadil Novalić and the serious economic situation in Bosnia and Herzegovina in which most citizens are having a hard time making ends meet. Projected to the blend from input space two is the concept of life in luxury. Projected to the blend from input space three is illegal organ trade caused by poverty. The absurd scenario that arises in the blend creates humorous effects. In the blend, Bosnians are asking the prime minister for forgiveness because they are complaining about the hard socio-economic situation, yet they are living in luxury as they can afford to keep their kidneys.

Furthermore, the Forgive me Fadil Internet campaign is referred to in the next meme, creating intertextual relations between humorous forms commenting on the same issue. 
(7)

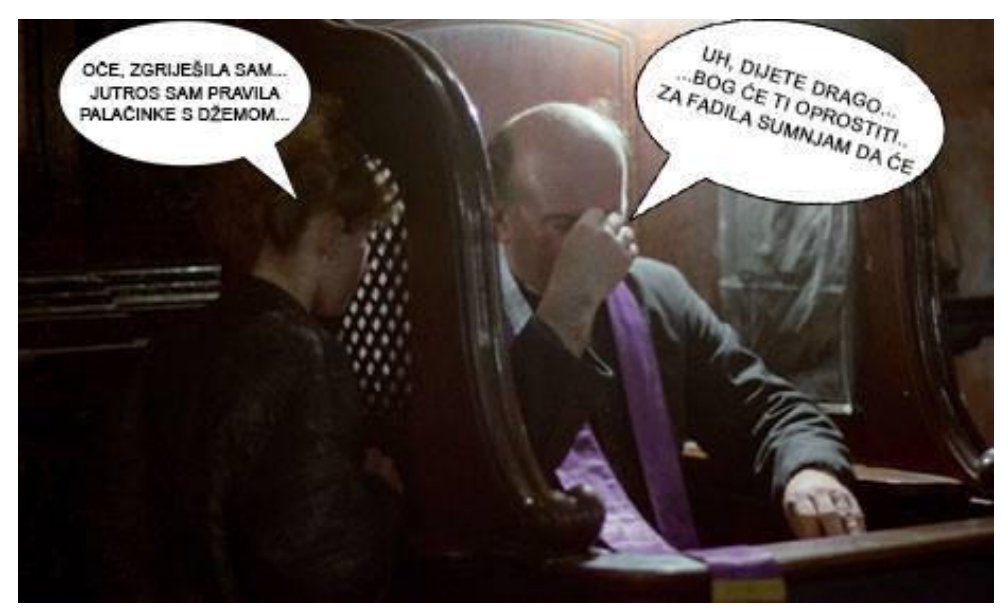

Figure 7. Forgive me Fadil. Source: Facebook

The meme presents a typical scene from the Catholic Church tradition, where a woman in confession is asking for the absolution of sins. This static image is edited and accompanied by the words uttered by the woman and the priest. In the captions, written in Bosnian, the woman says: 'Father, I have sinned. I made crêpes with jam this morning'. The priest responds by saying: 'Oh, dear child. God will forgive you, but I doubt Fadil will'. The expression on the priest's face, as well as his gesturing, further reiterate the priest's worry that the situation is helpless.

As in the previous example, the humorous meaning of the meme is created in a five-space integration network. Input space one contains Novalić's statement about luxurious life in Bosnia and Herzegovina, as well as the hard socio-economic situation in Bosnia and Herzegovina, where a significant number of people are struggling to live a normal life. As in the previous example, input space two contains the life in luxury, with all of the advantages of being rich, especially extravagant spending. Input space three contains the scenario of confession of sins in Catholic Church, in which the faithful ask for absolution from the sins committed against God. Only God has the power to grant absolution for the sins committed.

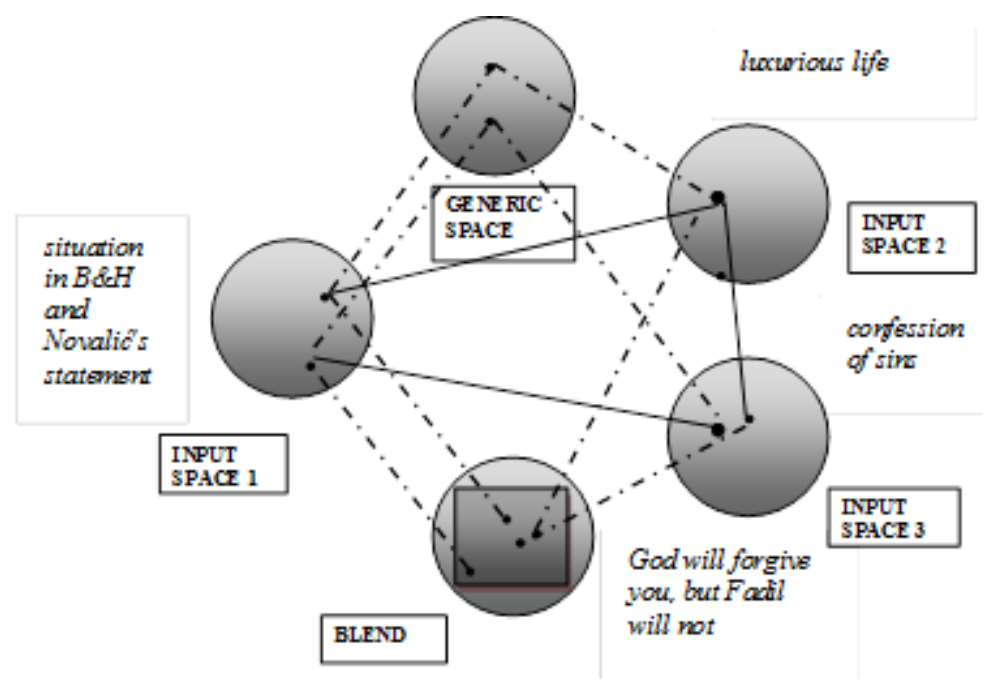

Figure 8 . The conceptual integration network for the confession meme 
As in the previous examples, cross-space mappings connect the wasteful spending mentioned in Novalić's claims from input space one to the luxurious lifestyle from input space two. These two spaces are linked by overconsumption of food and drink. In input space one, Bosnians are spending too much on groceries and are living recklessly. In addition, what all religions propagate is moderation, including moderation in consumption of food and drink, with gluttony being one of seven deadly sins in the Catholic tradition. The blend inherits the organising frame from input space three. Projected to the blend from input space one is Fadil Novalić and his statements on wasteful spending and Bosnians asking for his forgiveness for living a normal life. Also projected to the blend are luxurious life from input space two and the concept of asking for absolution from sins in the Catholic tradition from input space three. In the bizarre scenario created in the blend, a Bosnian in confession is asking for forgiveness for being wasteful and having crêpes with jam. The priest can assure her that God will forgive her, but Fadil will not, making Fadil's authority even greater than God's.

The Forgive me Fadil campaign also included humorous photographs posted by social network users. These memetic photographs were either digitally edited using computer tools or simply accompanied by a text asking for Fadil's forgiveness or permission to do something. In that sense, a Facebook user posted a picture of his broken leg in the cast which the author decorated with the text saying: "\#ForgivemeFadil Fadil would continue walking without the cast!!! Keep walking”.

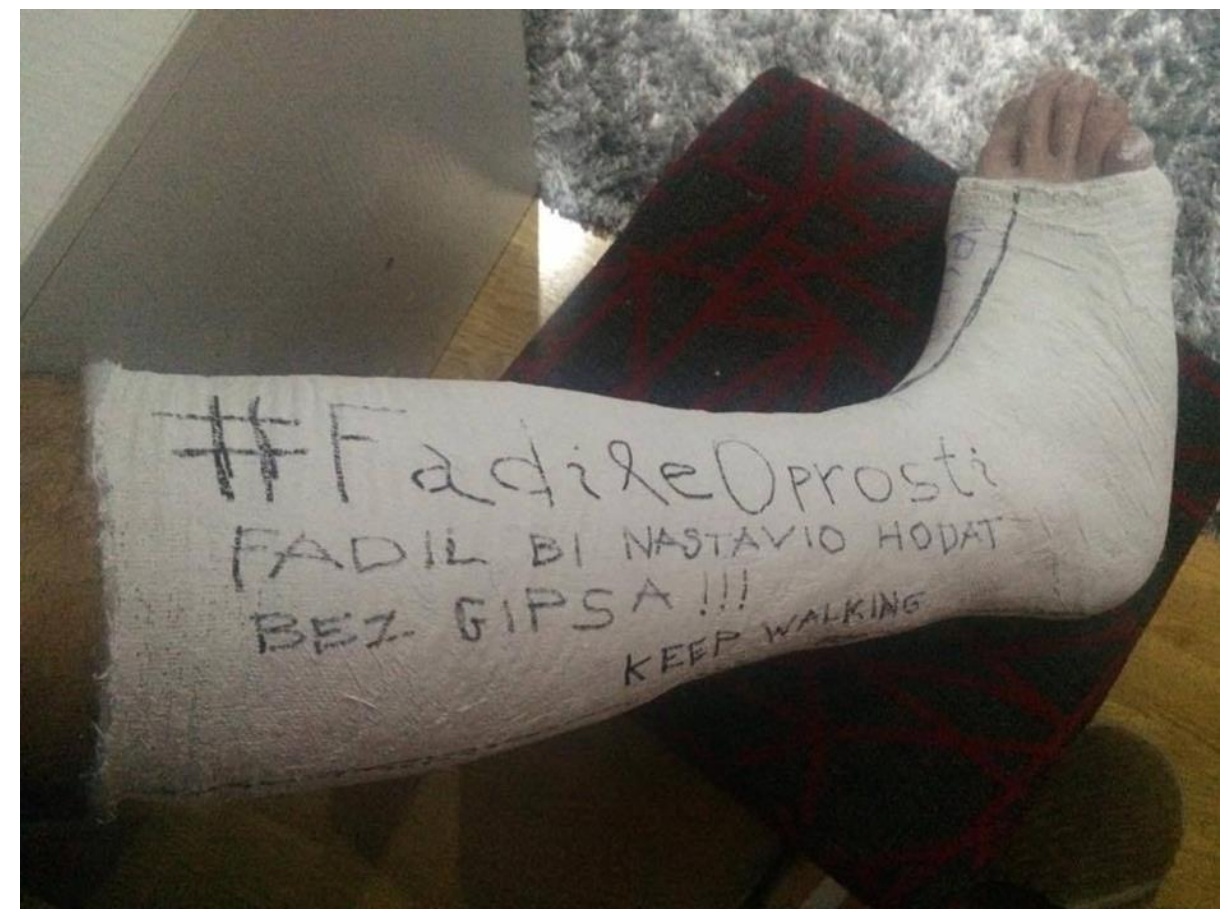

Figure 9. Forgive me Fadil for this broken leg. Source: Facebook

This humorous Internet form resembles the famous Chuck Norris jokes, which are well-known around the world. These jokes focus on Norris's masculinity, virility, heroism, attitude and toughness. The main point of these jokes is that the impossible is simply possible for Chuck Norris. Thus, Chuck Norris can divide by zero, Chuck Norris makes onions cry or Chuck Norris can delete the Recycling Bin. The author of this humorous form obviously exploited his knowledge about Chuck Norris and his supernatural abilities, which he recognised in Fadil 
Novalić as well. In that sense, Fadil Novalić can be seen as the Chuck Norris of Bosnia as he is able to make a living on bare necessities a luxurious life.

The meaning of this humorous memetic photograph is created in a five-space integration network composed of a generic space, three input spaces and a blended space. Input spaces one and two are the same as in all other examples. Therefore, input space one contains Fadil Novalić and his statement, as well as the everyday struggle of Bosnians to afford bare necessities to survive. Input space two contains luxurious lifestyle only the rich can afford. Input space three contains the knowledge about human anatomy, or to be more precise, the knowledge about leg fracture. Treatment of a broken leg usually includes having a leg in a plaster cast to hold the bone in place.

Cross-space mappings connect wasteful spending mentioned in Novalić's claims from input space one to the luxurious lifestyle from input space two. In addition, inputs one and three are connected by the fact that people need bare necessities to survive, that is, it is necessary to eat and drink just as it is necessary to place a broken leg in a plaster cast so a person can walk again. The blend receives the organising frame from both input space one and input space three. Projected to the blend from input space one are Novalić and his claim about reckless spending in Bosnia. Projected to the blend from input space two is being able to afford luxury items. The blend also receives projections from input space three that include leg fracture and the treatment of such injury. The absurd scenario that arises in the blend contains an unusual combination of structures, that is, the incongruity, which produces humorous effects. In the blend, Fadil Novalić would continue walking without a cast, which is, according to the prime minister, considered to be a luxury in Bosnia and Herzegovina. The fact that a cast on a broken leg is considered a luxury in Bosnia and Herzegovina yields incongruity, which produces humorous effects.

Novalićs supernatural powers to live a life in luxury on a bare minimum are further reiterated in a joke which appeared on an Internet forum, in which Fadil showed his superiority even over Chuck Norris.

(9) Chuck Norris se samo jednom izvinio i to Fadilu!

[Chuck Norris apologised only once. To Fadil.]

The humorous meaning of this joke is created in a four-space network composed of two input spaces, a generic space and a blended space. Input space one contains the whole Forgive me Fadil Internet campaign, including Novalić's statement and the humorous apologises to Fadil people posted on social networks for living a normal life. Input space two contains Chuck Norris and his masculinity, heroism, attitude, toughness, or simply his supernatural abilities to make the impossible possible. 


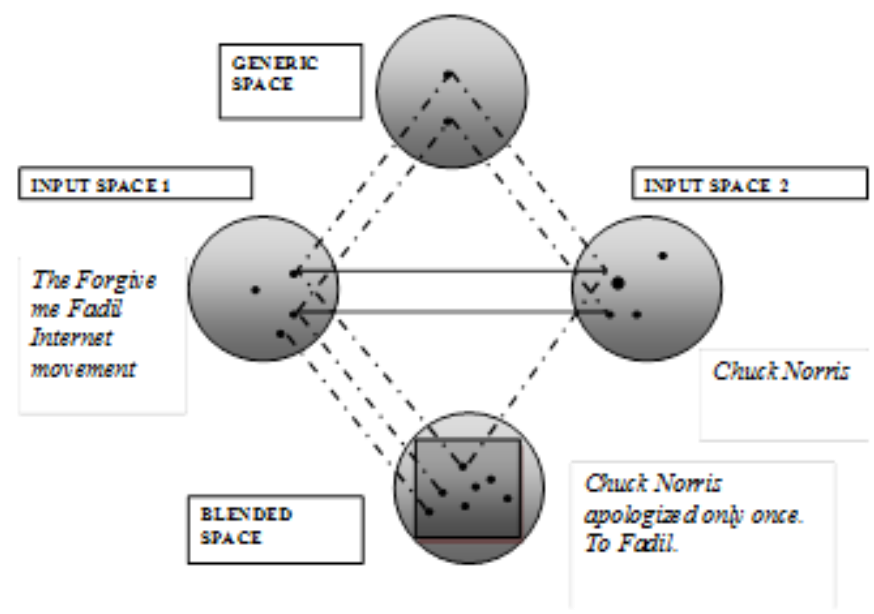

Figure 10. The conceptual integration network for the Chuck Norris-Fadil joke

Cross-space mappings connect Fadil Novalić from the Forgive me Fadil campaign from input space one to Chuck Norris from input space two as both of them can do unimaginable things. Projected to the blend from input space one are Fadil Novalić and his superpowers to live a luxurious life only on bare necessities, as well as people asking for his forgiveness for enjoying luxuries. Chuck Norris with his superpowers is projected to the blend from input space two. In the absurd scenario created in the blend, which contains an unusual combination of structures, Chuck Norris does the impossible and apologises to Fadil Novalić for being wasteful.

In another memetic photograph posted on Facebook, the author served for lunch a plate of rice with a piece of paper on which he drew a chicken drumstick. The text accompanying this photograph says:

(10) Fadile, može li ovako? Nema para za batak.

[Fadil, is it ok like this? No money for a drumstick.]

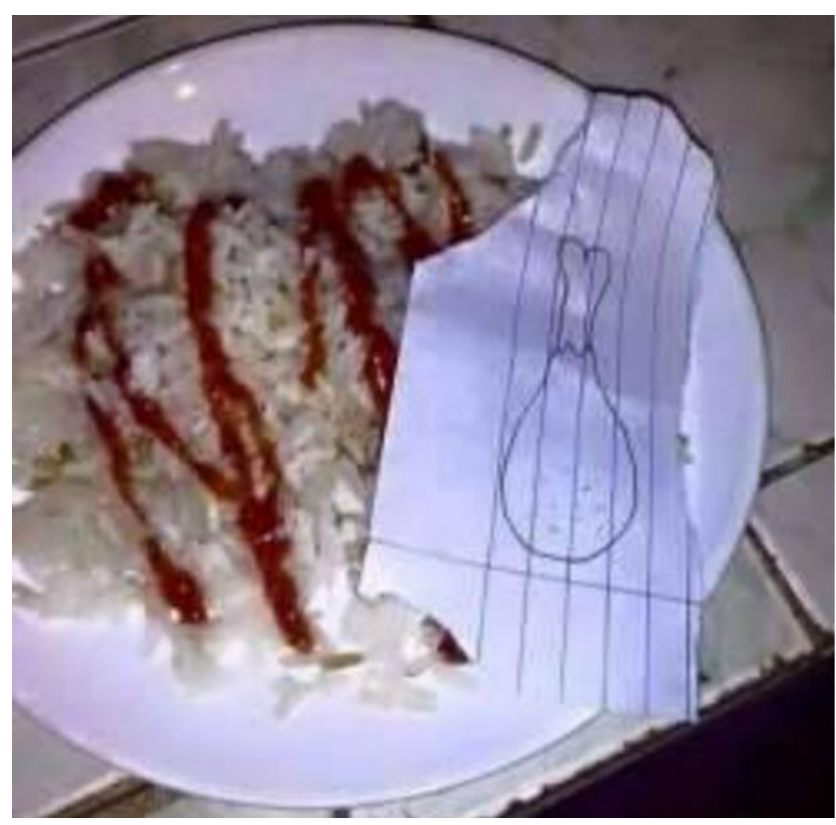

Figure 11. Is it ok like this, Fadil? Source: Facebook 
The humorous meaning of this memetic photograph is created in a four-space conceptual integration network. As in the other examples, input space one contains the socio-economic situation in Bosnia and Herzegovina and Novalić and his statement. Input space two contains human nutrition, or more precisely, a balanced diet for average adults composed of recommended doses of certain nutrients found in fruits, vegetables, grains, meats and dairy. Cross-space mappings connect groceries which people in Bosnia spend on from input space one and a balanced diet from input space two. Projected from input space one are Fadil Novalić, products Bosnians spend on in supermarkets and the creativity of Bosnians to survive on a bare minimum. Projected to the blend from input space two is a balanced meal composed of chicken and rice. In the absurd scenario created in the blend, a Bosnian is asking for Fadil's approval to have a lunch composed of rice and a drumstick drawn on a piece of paper, the only meat he can afford.

\section{The creation of humorous meaning in conceptual blending}

In all of the examples of humorous Internet forms we have discussed above, the absurd scenarios that arise in the blend contain unusual combinations of structures, that is, incongruity. These bizarre scenarios include asking Fadil for forgiveness in various situations and for different reasons, namely, having crêpes with jam for breakfast, having two kidneys, washing the dishes with lukewarm water or having a cast on a broken leg. In addition, as Fadil Novalić in these absurd scenarios has authority greater than the Godfather, God or Chuck Norris, people must ask for his permission to eat paper drumsticks. The fact that a bare minimum people in Bosnia and Herzegovina live on can be considered a luxurious life by the prime-minister yields the incongruity in these blends, producing humorous effect. Thus, the incongruity created in the blended space is the key element for the creation, as well as appreciation of humorous meaning. The resolution of the incongruity, and thus understanding of humour, is realised by backward projections from the blend into inputs, that is, unpacking the blend. Therefore, the incongruity prompts the reader to unpack the blend by looking for the inputs.

In verbal jokes the target of the ridicule is often very clear, however, pictorial components in memes, demotivational posters, and memetic photographs can leave room for different interpretations of the intended humorous meaning. The visual nature of these forms poses interpretative riddles before the readers. Thus, the reader has to solve an interpretative puzzle composed of verbal and pictorial elements in order to understand the humorous meaning of these forms of humorous expression. Therefore, in the memes, demotivational posters, and memetic photographs, the reconstruction of the integration network is, apart from verbal elements, also guided by pictorial elements of which these forms are composed. Furthermore, it is important to mention that the understanding of humour in these examples, as well as other humorous examples, depends on the reader's knowledge. In this case, it is the knowledge of a particular political event in Bosnia and Herzegovina, political actors and their views creatively exploited in these humorous Internet forms. In addition, the reader has to be familiar with cultural models that such examples activate, as these forms exploit the shared cultural knowledge within a discourse community. Taking all of this into account, it has to be pointed out that the success of memes, demotivational posters, and memetic photographs in the virtual world depends on whether pictorial and verbal elements provide enough cues for the reader to activate the background knowledge and solve the puzzle.

Apart from resolving the incongruity created in the blend, backward projections from the blended space to input spaces reinforce construals in input spaces in accordance with the new structure created in the blend. Therefore, backward projections also highlight certain aspects of the scenarios in input spaces, and thus help achieving rhetorical goals. In that sense, in 
example (1) backward projections into input space one emphasize that Fadil Novalić has to be asked for everything, even for the type of groceries people buy every day. In the jokes (2)-(6), as well as the meme in (7), asking for Fadil's forgiveness for using bare necessities on a daily basis reiterates the absurdity of his claims that people in Bosnia and Herzegovina are having easy lives. On the contrary, backward projections to input space one in these jokes emphasise the fact that people in Bosnia and Herzegovina are hardly making ends meet let alone living in luxury. Furthermore, in example (8) backward projections to input space one further highlight the fact that people in Bosnia and Herzegovina should have superpowers, as Fadil Novalić, to do impossible things, that is, to survive on a bare minimum. In addition, in example (10), backward projections to input space one highlight the fact that people in Bosnia cannot afford to buy basic necessities such as ingredients for a balanced meal. Therefore, all of these examples reiterate that Novalić's claims are not only downright absurd but also offensive because having an easy life in Bosnia and Herzegovina is almost impossible for the majority of population.

Thus, as these examples show, the new structure created in the blend also successfully criticises the political situation, giving these humorous Internet forms rhetorical and argumentative power. Therefore, it can be claimed that conceptual blending produces a new meaning in the blended space, which is creative and amusing but which, at the same time, also criticises the absurdities of the real world. Considering their potentially serious rhetorical message, these forms of humorous expression give an opportunity to concerned citizens to become involved in the political life and possibly make a change in the society.

\section{Conclusion}

Applying conceptual integration theory, the paper shows how humorous meaning of various types of political Internet humour, including memes, demotivational posters, hashtag postsm and memetic photographs, is created in conceptual integration. In addition, it also touches upon the issue of rhetorical and argumentative potential of political Internet humour, which, often regarded as trivial and absurd, provides critical comments on serious political issues and reveals social and cultural trends.

The humorous meaning of different forms of Internet forms is created in conceptual integration as a basic cognitive operation. Humour is created in the blended space due to the unusual combination of related structures, which results in incongruity. The resolution of incongruity, and thus understanding of the humorous meaning, is done by recognizing the incongruity based on which the blend is unpacked into input spaces. It is important to emphasise that the understanding of humour depends on the reader's knowledge. In addition, the success of this type of humorous expression depends on whether pictorial and/or verbal elements provide enough cues for the reader to activate the background knowledge and solve the interpretative puzzle posed before the reader.

Apart from explaining the creation of humorous meaning, conceptual integration theory can reveal why humour has rhetorical potential. Backward projections from the blend into inputs highlight certain aspects of input spaces and cast a new light onto these scenarios, now viewed in accordance with the comic effect created in the blend. Thus, bizarre scenarios created in the blend actually have very serious messages. Therefore, various forms of political Internet humour, ranging from hashtag posts to memes, as products of conceptual integration, point out humorous aspects of serious political situations and have rhetorical and argumentative potential.

As the examples we have analysed show, the contemporary digital era has created a free space for voicing opposition to incompetent and arrogant politicians in the form of verbal, 
visual and audio-visual content that is transferred quickly via the Internet from user to user. Whether these humorous forms of political criticism can make political actors seriously consider issues raised humorously and whether they can mobilise people to take serious political action has yet to be seen. Nevertheless, what is certain is that the new forms of humorous political expression in the cyber space have opened up a new space for expressing political opinions and have allowed political humour to make a transition from the private to the public sphere in a relatively new democracy such as Bosnia and Herzegovina.

\section{Notes}

1 Mark Turner's web site (www.markturner.org) summarises the research within the framework of conceptual integration theory in the period from 1995 to present. It is a presentation of the work carried out in the field of linguistics, as well as in other fields in which the theory has found its place.

${ }^{2}$ Bosnia and Herzegovina has a very complex political system reflecting the provisions of the Dayton Peace Accords signed to end the three-and-a half-year-long Bosnian war that lasted from 1992 to 1995. Bosnia and Herzegovina is composed of two entities, the Federation of Bosnia and Herzegovina, inhabited primarily by Bosniaks and Croats, and the Republika Srpska, inhabited primarily by Serbs, with each entity having its own legislature and government.

${ }^{3}$ As a consequence of the permanent political crisis and weak economic growth, Bosnia and Herzegovina is the poorest county in the region. Around $25 \%$ of the population is unemployed, with the youth unemployment rate of almost $60 \%$. For those employed, the average monthly salary is around 400 Euros. Considering the grave economic situation, the majority of citizens of Bosnia and Herzegovina live only just above the poverty line.

${ }^{4}$ Shifman (2013: 41) defines an Internet meme as "(a) a group of digital items sharing common characteristics of content, form and/or stance, which (b) were created with awareness of each other, and (c) were circulated, imitated, and/or transformed via the Internet by many users." The main characteristics of Internet memes are simple packaging, humour and participation tools (Shifman 2013: 94-97).

\section{References}

Berberović, S. \& Delibegović Džanić, N. (2009). 'Političari, dvorske dame i kajgana: Teorija konceptualne integracije i politički humor', in Brdar, M, Omazić, M., Belaj, B. \& Kuna, B. (eds.), Lingvistika javne komunikacije: Sociokulturni, pragmatički $i$ stilski aspekti, Zagreb/Osijek: HDPL, pp. 139-153.

Berberović, S. \& Delibegović Džanić, N. (2015). 'Bitno je biti...? - Teorija konceptualne integracije i internetski politički memovi', in Belaj, B. (ed.), Dimenzije značenja, Zagreb: Zagrebačka slavistička škola, pp. 9-30.

Bergen, B. (2004). 'To awaken a sleeping giant: Blending and metaphor in editorial cartoons after September 11', in Achard, M. \& Kemmer, S. (eds.), Language, Culture, and Mind, Stanford: CSLI Publications, pp. 23-36.

Coulson, S. (1996). 'The Menendez Brothers Virus: Analogical mapping in blended spaces', in Goldberg, A. (ed.), Conceptual Structure, Discourse, and Language, Stanford, CA: CSLI, pp. 67-81.

Coulson, S. (2002). 'What's so funny: Conceptual blending in humorous examples'. Available at: http://www.cogsci.ucsd.edu/ coulson/funstuff/funny.html 
Coulson, S. (2005). 'Extemporaneous blending: Conceptual integration in humorous discourse from talk radio'. Style 39, pp. 107-122.

Coulson, S. (2006). 'Conceptual blending in thought, rhetoric, and ideology', in Kristiansen, G., Achard, M., Dirven, R. \& Ruiz de Mendoza Ibáñez, F.J. (eds.), Cognitive Linguistics: Current Applications and Future Perspectives. Berlin/New York: Mouton de Gruyter, pp. 187-210.

Coulson, S. \& Oakley, T. (2000). 'Blending basics'. Cognitive Linguistics 11 (3/4), pp. 175196.

Coulson, S. \& Oakley, T. (2006). 'Purple persuasion: Conceptual blending and deliberative rhetoric', in Luchenbroers, J. (ed.), Cognitive Linguistics Investigations: Across Languages, Fields and Philosophical Boundaries. Amsterdam/Philadelphia: John Benjamins, pp. 47-65.

Coulson, S. \& Pascual, E. (2006). 'For the sake of argument: Mourning the unborn and reviving the dead through conceptual blending'. Annual Review of Cognitive Linguistics 4, pp. 153181.

Delibegović Džanić, N. (2013). 'Who was born with a silver foot in his mouth? Modified idiomatic expressions in political cartoons'. Jezikoslovlje 14 (2-3), pp. 323-336.

Delibegović Džanić, N. \& Berberović, S. (2010). 'On politicians in big women's sunglasses driving buses with their feet in mouths: Late-night political humour and conceptual integration theory'. Jezikoslovlje 11 (2), pp. 197-214.

Delibegović Džanić, N. \& Berberović, S. (2014). 'Hot cakes: The use of idioms in political cartoons', in Jesenšek, V. \& Dobrovol'skij, D. (eds.), Phraseology and Culture, BielskoBiala, Budapest, Kansas, Maribor; Praha: Zora, pp. 339-353.

Delibegović Džanić, N. \& Omazić, M. (2011). 'Conceptual blending in political cartoons', in Tomović, N. \& Vujić, J. (eds.), English Language and Literature Studies: Image, Identity, Reality, Belgrade: Faculty of Philology, University of Belgrade, pp. 51-64.

Fauconnier, G. (1985). Mental Spaces. Cambridge, Massachusetts: The MIT Press.

Fauconnier, G. (2007). 'Mental spaces', in Geeraerts, D. \& Cuyckens, H. (eds.), The Oxford Handbook of Cognitive Linguistics, Oxford: Oxford University Press, pp. 351-376.

Fauconnier, G. \& Turner, M. (2000). 'Compression and global insight'. Cognitive Linguistics $11(3 / 4)$, pp. 283-304.

Fauconnier, G. \& Turner, M. (2002). The Way We Think: Conceptual Blending and the Mind's Hidden Complexities. New York: Basic Books.

Fauconnier, G. \& Turner, M. (2006). 'Conceptual integration networks', in Geeraerts, D. (ed.), Cognitive Linguistics: Basic Readings, Berlin: Mouton de Gruyter, pp. 303-371. Reprint of 'Conceptual integration networks'. (1998). Cognitive Science 22 (2), pp. 133-187.

Grady, J., Oakley, T. \& Coulson, S. (1999). 'Conceptual blending and metaphor', in Gibbs, R. W. Jr. \& Steen, G.J. (eds.), Metaphor in Cognitive Linguistics. Amsterdam/Philadelphia: John Benjamins, pp. 101-124.

Koestler, A. (1964). The Act of Creation. London: Hutchinson.

Kyratzis, S. (2003). 'Laughing metaphorically: Metaphor and humour in discourse'. Paper presented at the 8th International Cognitive Linguistics Conference. Logroño, 20-25 July. Available at http://wwwling.arts.kuleuven.ac.be/iclc/Papers/Kyratzis.pdf.

Lundmark, C. (2003). 'Puns and blending: The case of print advertisements'. Paper presented at the 8th International Cognitive Linguistics Conference. Logroño, 20-25 July. Available at http://wwwling.arts.kuleuven.ac.be/iclc/Papers/Lundmark.pdf.

Marín-Arrese, J. I. (2003). 'Humour as ideological struggle: The view from cognitive linguistics'. Paper presented at the 8th International Cognitive Linguistics Conference. Logroño, 20-25 July. Available at http://wwwling.arts.kuleuven.ac.be/iclc/Papers/JuanaMarinArrese.pdf. 
Oakley, T. \& Coulson, S. (2008). 'Connecting the dots: Mental spaces and metaphoric language in discourse', in Oakley, T. \& Hougaard, A. (eds.), Mental Spaces in Discourse and Interaction. Amsterdam/Philadelphia: John Benjamins, pp. 27-50.

Shifman, L. (2013). Memes in Digital Culture. Cambridge, Massachusetts: The MIT Press.

Turner, M. (2007). 'Conceptual integration', in Geeraerts, D. \& Cuyckens, H. (eds.), The Oxford Handbook of Cognitive Linguistics, Oxford: Oxford University Press, pp. 377-393.

Turner, M. \& Fauconnier, G. (1995). 'Conceptual integration and formal expression'. Metaphor and Symbolic Activity 10 (3), pp. 183-204.

Turner, M. \& Fauconnier, G. (1999). 'A mechanism of creativity'. Poetics Today 20(3), pp. 297-418.

Turner, M. \& Fauconnier, G. (2003). 'Metaphor, metonymy, and binding', in Dirven, R. \& Pörings, R. (eds.), Metaphor and Metonymy in Comparison and Contrast. Berlin: Mouton de Gruyter, pp. 469-487. 